\title{
Pathogenicity, Symptom Development, and Colonization of Metrosideros polymorpha by Ceratocystis lukuohia
}

\author{
Marc A. Hughes, ${ }^{1, \dagger}$ Jennifer Juzwik, ${ }^{2}$ Thomas C. Harrington, ${ }^{3}$ and Lisa M. Keith ${ }^{4}$ \\ ${ }^{1}$ College of Tropical Agriculture and Human Resources, University of Hawaii at Mānoa, Hilo, HI 69720 \\ ${ }^{2}$ Northern Research Station, USDA Forest Service, St. Paul, MN 55108 \\ ${ }^{3}$ Department of Plant Pathology and Microbiology, Iowa State University, Ames, IA 50011 \\ ${ }^{4}$ Daniel K. Inouye U.S. Pacific Basin Agricultural Research Center, USDA Agricultural Research Service, Hilo, HI 96720
}

\begin{abstract}
Extensive mortality of Metrosideros polymorpha ('ōhi`a) trees has been associated with Ceratocystis spp. on Hawai' i Island and was named rapid 'ōhi 'a death (ROD). Both C. lukuohia and C. huliohia have been associated with ROD, although C. lukuohia appears to be the more important pathogen. Crown observations and dissections of forest trees either wound-inoculated with, or naturally infected by, C. lukuohia were conducted to confirm pathogenicity and document patterns of host colonization. In pathogenicity trials, one of three and two of three trees inoculated with the fungus in February and August, respectively, exhibited crown wilt symptoms at 92 and 69 days after inoculation. Extensive, radial,

May to June and harvested 37 to 42 days later, and these observations were compared with those in two naturally infected trees felled in early August. Contiguous xylem staining was found in the main stems and into crowns of all diseased trees, while discontinuous streaks of xylem staining extended into the main forks and side branches. Necrotic phloem associated with xylem staining occurred on the lower stems of inoculated trees. Aside from the necrotic phloem and radial staining of the sapwood, symptom development in `ohi`a infected with C. lukuohia is similar to other systemic wilt diseases on hardwood trees. We propose Ceratocystis wilt of 'ohi`a as the official name of the disease.
\end{abstract} black staining of the sapwood was found in main stems, while no crown wilt or xylem staining was found in control trees. Xylem staining, necrotic phloem, and fungus presence was noted in six trees inoculated in
Keywords: `ōhi`a, rapid `ōhi`a death, vascular wilt disease, Hawai` i, fungi, trees
'Ohi a (Metrosideros polymorpha Gaudich.) is a keystone species to Hawaiian native forests and a critical component to the islands' watersheds. On Hawai i Island, 'ōhi'a occupies nearly 250,000 ha of forest land and is the most abundant native tree. Highly variable in form, 'ōhi'a is common across all islands of the state and can live in a variety of habitats from wet lowlands at sea level to upper elevation dry forests (Dawson and Stemmerman 1990). As an early colonizer of new lava flows, 'ohi 'a is integral to the succession of Hawai i's landscape, turning once barren lands into young monotypic stands that can later become diverse forests (Fig. 1A and B). Due to its landtransforming characteristics, the critical habitat it provides for endangered flora and fauna, and the extensive use of its wood, flowers, and other parts for cultural purposes, 'ōhi'a holds tremendous utility and value to the people of Hawai i (Mueller-Dombois et al. 2013).

Beginning in 2010, reports of an uncommon and rapid mortality of 'ôhi a in the Puna District of southeastern Hawai i Island spurred investigations into its cause. Unlike earlier stand diebacks observed

Current address of M. A. Hughes: Institute of Pacific Islands Forestry, USDA Forest Service, Hilo, HI 96720

${ }^{\dagger}$ Corresponding author: M. A. Hughes; mhughes7@ hawaii.edu

Funding: U.S. Forest Service (Region 5 State and Private Forestry); The Hawaii Department of Land and Natural Resources; U.S. Forest Service (Washington Office, Forest Health Protection).

*The $\boldsymbol{e}$-Xtra logo stands for "electronic extra" and indicates that two supplementary figures are published online.

The author(s) declare no conflict of interest.

Accepted for publication 4 February 2020.

This article is in the public domain and not copyrightable. It may be freely reprinted with customary crediting of the source. The American Phytopathological Society, 2020. decades ago, where the synchronized and gradual decline of canopy trees were primarily attributed to unfavorable environmental and abiotic conditions (Hodges et al. 1986; Mueller-Dombois 1985; Petteys et al. 1975), the recent mortality is patchy in distribution and progresses rapidly in trees and within stands. In general, symptoms include black staining of sapwood, crown wilt, and tree death (Fig. 1C and D) (Barnes et al. 2018; Keith et al. 2015). This mortality is commonly referred to as rapid 'ohi`a death (ROD) and has spread across the island to become the most damaging epiphytotic on 'ōhi`a.

Using aerial imagery, Mortenson et al. (2016) described an increase in forest areas with suspected ROD mortality (stands with greater than $10 \%$ mortality) from 1,600 ha in 2012 to 6,400 ha in 2014 in the affected region. Currently (late 2019), suspected ROD mortality has been confirmed in all districts of Hawai i Island. Remote sensing during mid-June 2017 flights detected nearly 43,000 'ōhi' a trees with brown leaves and over 500,000 leafless crowns on Hawai i Island (Asner et al. 2018; Vaughn et al. 2018). Aerial digital sketch mapping has estimated over 76,083 ha of forest affected by ROD on Hawai i Island (B. Tucker, personal communication); though ground-truthing is needed to verify the causal agent(s).

Keith et al. (2015) first reported the ROD pathogen as Ceratocystis fimbriata Ellis \& Halst. based on pathogenicity, morphology, and ITS rDNA sequences, and they referred to the disease as Ceratocystis wilt. However, a second Ceratocystis sp. was associated with RODlike mortality, and further DNA sequencing, molecular marker analysis, host range testing, and fungal mating assays concluded that two novel and distinct species, C. lukuohia I. Barnes, T.C. Harrin. \& L.M. Keith and C. huliohia I. Barnes, T.C. Harrin. \& L.M. Keith, were capable of causing mortality of 'ōhi a seedlings (Barnes et al. 2018). The new species are closely related to but distinct from earlier reported Ceratocystis spp. on Araceae in Hawaii, a Syngonium strain of $C$. fimbriata that is closely related to C. platani (J.M. Walter) Engelbr. \& T.C. Harrin. and C. uchidae Q. Li, D. McNew \& T.C. Harrin. on taro (Colocasia esculenta) (Li et al. 2017; Thorpe et al. 2005). Pathogenicity tests with $C$. lukuohia and $C$. huliohia on `ōhì seedlings resulted in similar wilt and xylem stain symptoms, yet these species failed to induce symptoms in taro, Syngonium, or London plane 
(Plantanus $\times$ acerifolia) (Barnes et al. 2018). Currently, C. lukuohia and $C$. huliohia have been reported on Hawai $\mathrm{i}$ Island and Kaua $\mathrm{i}$ (Brill et al. 2019; Heller et al. 2019), and only C. huliohia has been found on Mau `i and O`ahu (Dennison 2019).

Although both fungi caused xylem staining, wilt, and mortality in inoculated seedlings, observations of naturally infected trees in the field suggested substantial differences in external and internal symptomatology (Barnes et al. 2018). Trees infected by C. lukuohia generally show rapid crown wilt with extensive radial vascular streaking in the sapwood. Conversely, the crown symptoms associated with C. huliohia tend to develop more slowly and are sometimes associated with wilt of individual limbs, which may eventually lead to tree death. With $C$. huliohia, internal vascular discoloration may be patchy in distribution and appear diffuse in cross sections. Although both species have been recovered from dead and dying trees, $C$. lukuohia appears to be the more aggressive of the two pathogens and is associated with the vast majority of the 'ōi`a mortality across the island (Barnes et al. 2018).

The goal of this research was to characterize the disease caused by C. lukuohia in a series of field inoculation studies and in naturally infected trees. The symptomology and internal host colonization by the fungus were assessed to 1) fulfill Koch's postulates on wild-grown trees, and 2) document the pattern of internal colonization of the trees by the fungus. Based on our findings we propose the name Ceratocystis wilt of 'ôhi a for the disease caused by $C$. lukuohia. Furthermore, we discuss the role of Ceratocystis wilt in the greater context of ROD-associated mortality in Hawaiian forests.

\section{Materials and Methods}

Site and tree selection for inoculations. Studies were conducted at the Keaukaha Military Reservation (KMR) $\left(19^{\circ} 42^{\prime} 54.71^{\prime \prime} \mathrm{N}\right.$, $155^{\circ} 3^{\prime} 3.23^{\prime \prime} \mathrm{W}$ ) and Waiākea Forest Reserve (WFR) (19 $36^{\prime}$ $6.62^{\prime \prime} \mathrm{N}, 155^{\circ} 8^{\prime} 28.45^{\prime \prime} \mathrm{W}$ ) in Hilo, Hawai i. Both sites had healthy and diseased 'ôhì trees in the immediate vicinity. Eighteen asymptomatic, single-stem trees (mean DBH $=15.0 \pm 1.1 \mathrm{~cm}$ ) were selected, tagged with metal labels, and GPS coordinates recorded before inoculation.

Fungal isolates and inoculum production. C. lukuohia was isolated from two diseased trees at WFR by baiting discolored sapwood between two carrot slices (Moller and DeVay 1968). One fungal isolate per diseased tree was made by transferring a single ascospore mass from a single perithecium on the colonized carrot slice to $10 \% \mathrm{~V} 8$ media amended with streptomycin $(100 \mathrm{mg})$. Isolates P15-02 and P17-70 were obtained in 2015 and 2017, respectively.

Two inoculum types were used. For the agar slurry inoculum, $3 \mathrm{ml}$ of a fungal suspension was uniformly spread onto a Petri plate ( $25 \mathrm{~mm}$ deep, $100 \mathrm{~mm}$ diam.) of $10 \% \mathrm{~V} 8$ or $2 \%$ malt yeast extract agar (MYEA) media and allowed to air dry under a laminar flow hood for $10 \mathrm{~min}$, followed by the addition of $6.0 \mathrm{ml}$ of vegetable oil (Crisco) to completely cover the agar surface and encourage the production of aleurioconidia on the medium. Cultures were incubated as above for 10 to 20 days at $25^{\circ} \mathrm{C}$ and $38 \% \mathrm{RH}$ under continuous light. To prepare the slurry, five plates with the most abundant aleurioconidia (visible as melanized spores under $40 \times$ magnification) were selected. The vegetable oil was poured off the five plates and the colonized agar was added to an ethanol-sterilized blender with $50 \mathrm{ml}$ of sterile water and blended in $30 \mathrm{~s}$ increments until a smooth consistency was obtained. Inoculum was placed into sterile $5 \mathrm{ml}$ syringes (without the needle) and used within $24 \mathrm{~h}$.

To produce filter paper inoculum (Keith et al. 2015), the isolates were grown on MYEA or 10\% V8 agar media for 7 days. Culture plates were then flooded with $3 \mathrm{ml}$ of sterile water, agitated with a sterile glass rod with rubber policeman scraper (Walter Stern Inc. Port Washington, NY), and adjusted to $1.0 \times 10^{6}$ spores $/ \mathrm{ml}$ with a hemocytometer. Sterile filter paper discs (32 mm diameter) (Whatman, GE Healthcare UK Limited, Buckinghamshire, UK) were soaked in the fungal suspension for $1 \mathrm{~min}$, laid onto fresh media plates (one disc per plate), and incubated for 3 to 5 days at $25^{\circ} \mathrm{C}$ and $38 \% \mathrm{RH}$ under continuous light. Inoculum for negative controls (sterile filter paper or agar slurry) were made in an equivalent manner.
Host inoculations. For the pathogenicity trials, 12 trees were labeled PT 1 to 12, and their main stem was wounded at $1.4 \mathrm{~m}$ height using a circular hole-saw drill bit (35 mm dia.) (Hole Dozer, Milwaukee Tool, Brooksfield, WI) attached to a cordless drill. Wounds were made to a depth just beneath the vascular cambium, exposing fresh outer sapwood. The bark disc was carefully removed and $1 \mathrm{ml}$ of C. lukuohia agar slurry inoculum was applied uniformly over each circular wound. The bark-plugs were reinserted into the wound and sealed over with plumber's putty (Oatey, Cleveland, $\mathrm{OH}$ ).

Three trees were inoculated with C. lukuohia and three with sterile MYEA agar slurry (negative controls) in each of two experiments. The first inoculations were conducted in February 2017 at the WFR site with agar slurry of isolate P15-02. Trees received three to four wounds in each of two staggered rows, one row at $1.4 \mathrm{~m}$ height and one $10 \mathrm{~cm}$ higher, for a total of six to eight wounds per tree depending on the tree diameter. A second inoculation was conducted on 25 August 2017 at the KMR site with isolate P17-70. Trees received two wounds at breast height on opposite sides of the trunk. Trees were felled 92 and 69 days after inoculation (DAI), respectively.

To more closely examine the pattern of internal colonization, a third inoculation study of six trees (labeled IC 1 to 6 ) were inoculated with isolate P17-70 on 13 or 20 June 2017 at KMR. Three `ohi a trees received $C$. lukuohia colonized filter paper (IC 1 to 3 ) and three were treated with agar slurry inoculum (IC 4 to 6). Negative controls were not used in this experiment. Trees were inoculated as above with two wounds per tree on opposite sides of the stem and monitored for the development of crown wilt symptoms. Trees were felled between 37 and 42 DAI.

Tree harvest and dissection. For the February to May pathogenicity trial, fungus-inoculated trees had the outer bark shaved with a draw knife to expose and measure the extent of necrotic phloem in the field. Each fungus-inoculated tree was then felled and dissected into stem sections using a chainsaw, first in the area between the two rows of inoculation points and then longitudinally in 10 to $30 \mathrm{~cm}$ increments until stained sapwood was no longer discernable on the top surface of the cut stem section. The presence of vascular staining in the sapwood was recorded and three to seven wood disks $(2$ to $3 \mathrm{~cm}$ thick) per tree were collected for pathogen assays and transported to the laboratory. Negative control trees were left standing and the extent of phloem necrosis was measured as above. The sapwood below each control inoculation point was exposed with a hatchet, the extent of discoloration measured, and a single sapwood chip per wound was collected for pathogen baiting.

For the August to November pathogenicity trial, trees were felled by chainsaw, cut into $1.22 \mathrm{~m}$ long main stem sections (bolts), and labeled according to their height along the bole. The stem sections with stained sapwood were transported to USDA Agricultural Research Service, Pacific Basic Agricultural Research Center (USDA ARS PBARC) in Hilo for processing. Outer bark was removed with an ethanol sterilized drawknife and the extent of phloem necrosis and surface xylem discoloration assessed. Two wood discs ( $8 \mathrm{~cm}$ thick) were cut from each $1.22 \mathrm{~m}$ bolt at approximately 15 and $85 \mathrm{~cm}$ from the bottom of each bolt section. In general, seven to eight disks per tree were obtained to assay for $C$. lukuohia presence. The circumference of each disk and the circumference and depth of xylem staining (at four equidistant points) were measured and recorded. If phloem necrosis and/or sapwood stain was not visible in the control trees, disks were removed at the inoculation points.

For the pattern of internal colonization study, each artificially inoculated tree was felled and the main stem sequentially sectioned (1.22 m lengths) using a chainsaw. Specifically, stem sections (bolts) with staining visible on either end as well as portions of the upper crown that exhibited xylem stain were transported to USDA ARS PBARC. Each tree was reconstructed on the ground with the appropriate sections and drawings made of tree architecture, including location of each section. For trees IC 1 to 3, between 4 and 10 stem disks were removed at a stem height of 20 to $560 \mathrm{~cm}$, and for trees IC 4 to 6,7 to 12 sapwood disks were sampled at heights between 20 and $530 \mathrm{~cm}$. The circumference of each disk and the circumference 
and depth of xylem staining (at four equidistant points) were measured and recorded.

Naturally colonized trees. To examine the spread of C. lukuohia within naturally infected 'ôhi a, two naturally established trees in a residential neighborhood were donated for dissection by a landowner in Volcano, HI, in August 2017. The first tree (VT1) was $15.0 \mathrm{~m}$ tall, $26 \mathrm{~cm} \mathrm{DBH}$, with a 75\% wilted crown (approximately $75 \%$ of the crown area had wilted, browning, or dead leaves). The second tree (VT2) was $13.7 \mathrm{~m}$ tall, $24 \mathrm{~cm}$ DBH, with a $25 \%$ wilted crown. Prior to felling, presence of C. lukuohia was confirmed by qPCR assay of sapwood shavings (Heller and Keith 2018).

These two trees were felled and the main stems sectioned into $1.22 \mathrm{~m}$ long sections. Two cross sectional disks $(8 \mathrm{~cm}$ thick) were cut out by chainsaw on site at approximately 15 and $85 \mathrm{~cm}$ along the length of each bolt and their position along the height of the bole labeled. Portions of the treetops (main branches and attached branches that exhibited sapwood stain) were also cut in the field. All disks and canopy sections were transported to USDA ARS PBARC and each tree reconstructed on the ground. Sapwood disks (11 and 16 per tree, respectively) were removed at a height ranging from 20 to 980 and 20 to $940 \mathrm{~cm}$ tall from VT1 and VT2. Additional wood disks were removed from branches. The circumference of each disk and the circumference and depth of xylem staining (at four equidistant points) was measured and recorded.

Fungus bioassay. To assess the distribution of viable C. lukuohia within the tree, carrot baiting was attempted on sapwood chips taken from along the main bole. When possible, pieces of phloem from the upper crown along the interface between healthy and necrotic tissue was also baited. Thin xylem or phloem sections ( 2 to $3 \mathrm{~mm}$ thick) were removed from the wood disks with an ethanol-sterilized chisel. For naturally infected trees (VT1 and VT2), similar baiting also was attempted from subsamples of small branches. To assess radial (inward) fungal colonization of wood disks obtained from lower stem sections, thin sections were sampled at $1 \mathrm{~cm}$ increments from the cambium.

Fungus isolation was attempted by using a modified carrot baiting technique (Moller and DeVay 1968). When possible, three replicate carrot baits were made per wood disc. Briefly, fresh carrot roots were sliced into discs ( $5 \mathrm{~mm}$ thick). In most cases, the roots were surface disinfested with $80 \%$ ethanol and peeled before slicing. Thin sections of symptomatic phloem or xylem were placed between two carrot discs, wrapped in laboratory film (Parafilm, Bemis Co. Inc., Oshkosh, WI), and individually bagged and incubated at room temperature. The symptomatic sections were usually misted with sterile water before placing between the carrot slices. Sample bags were periodically misted with sterile water to retain moisture and rated positive for $C$. lukuohia when grayish mycelia with perithecia and ascospore masses were visible. Small pieces of fungus-colonized carrot were excised by scalpel and assayed by qPCR (Heller and Keith 2018) if the mycelia appeared to be Ceratocystis but did not produce perithecia (e.g., due to bacterial contamination of the carrot).

To confirm that the perithecia on the carrot slices were C. lukuohia, ascospore masses were aseptically transferred from perithecia on the carrot baits to $10 \%$ V8 media, incubated for 10 to 12 days, and visually assessed for morphological characteristics, completing Koch's postulates (for pathogenicity trials). Additionally, the identity of $C$. lukuohia from at least three perithecia-positive carrot baits per each inoculated tree in the internal colonization study ( $n=36$ baits) and the two naturally infected trees ( $n=6$ baits) was confirmed by qPCR (Heller and Keith 2018).

\section{Results}

Pathogenicity of $\boldsymbol{C}$. lukuohia on field grown trees. For the February to May trial, one of three fungus-inoculated trees (PT 3) had a crown that was approximately $65 \%$ brown and wilted at 92 days. The other two C. lukuohia-inoculated showed no crown symptom at 92 DAI (Table 1). Total length of necrotic phloem in fungusinoculated trees ranged from $44 \mathrm{~cm}$ to greater than $132 \mathrm{~cm}$ (Fig. $2 \mathrm{~A})$. The tree with wilt symptoms had the most necrotic phloem. Total length of xylem staining ranged from 221 to $1,146 \mathrm{~cm}$ for the three trees. In two of three trees, the extent of phloem necrosis and xylem staining was much greater above the inoculation points than below (Fig. 2A).

During dissection, it became evident that the lower bole of PT 2 was composed of three small fused stems and the wood grain was highly contorted, likely limiting the upward extent of xylem staining (Fig. 2A). Tree PT 3 had extensive xylem staining that extended from the inoculation points to nearly the top of the tree crown's main fork (Fig. 2A). It was evident that staining had split at a branch fork $280 \mathrm{~cm}$ above the inoculation points. The staining was primarily seen in the larger diameter fork that supported nearly two-thirds of the tree's crown, which was completely wilted, while the smaller fork was much less extensively stained and had no wilt.

C. lukuohia was isolated from the stained sapwood of all wood discs taken from inoculated trees (Table 1). For the trees with no crown symptoms (PT 1 and 2), C. lukuohia was recovered from the sapwood at a maximum distance of 300 and $55 \mathrm{~cm}$ above inoculation points, respectively (Fig. 2A). For the partially wilted tree (PT 3), C. lukuohia was detected in sapwood discs $1,030 \mathrm{~cm}$ above the inoculation sites (Fig. 2A). Mock-inoculated trees (PT 4 to 6) were externally asymptomatic and showed very limited phloem necrosis around the wounds and only faint sapwood discoloration in the immediate vicinity $(<1 \mathrm{~cm})$ of the wounds (Fig. 2A). All samples from the control trees were negative in the carrot baiting assay.

For the August to November pathogenicity trial, fungus-inoculated trees PT 7 and PT 9 showed complete crown wilt (100\%) with reddish-brown foliage throughout the crown, while PT 8 and all
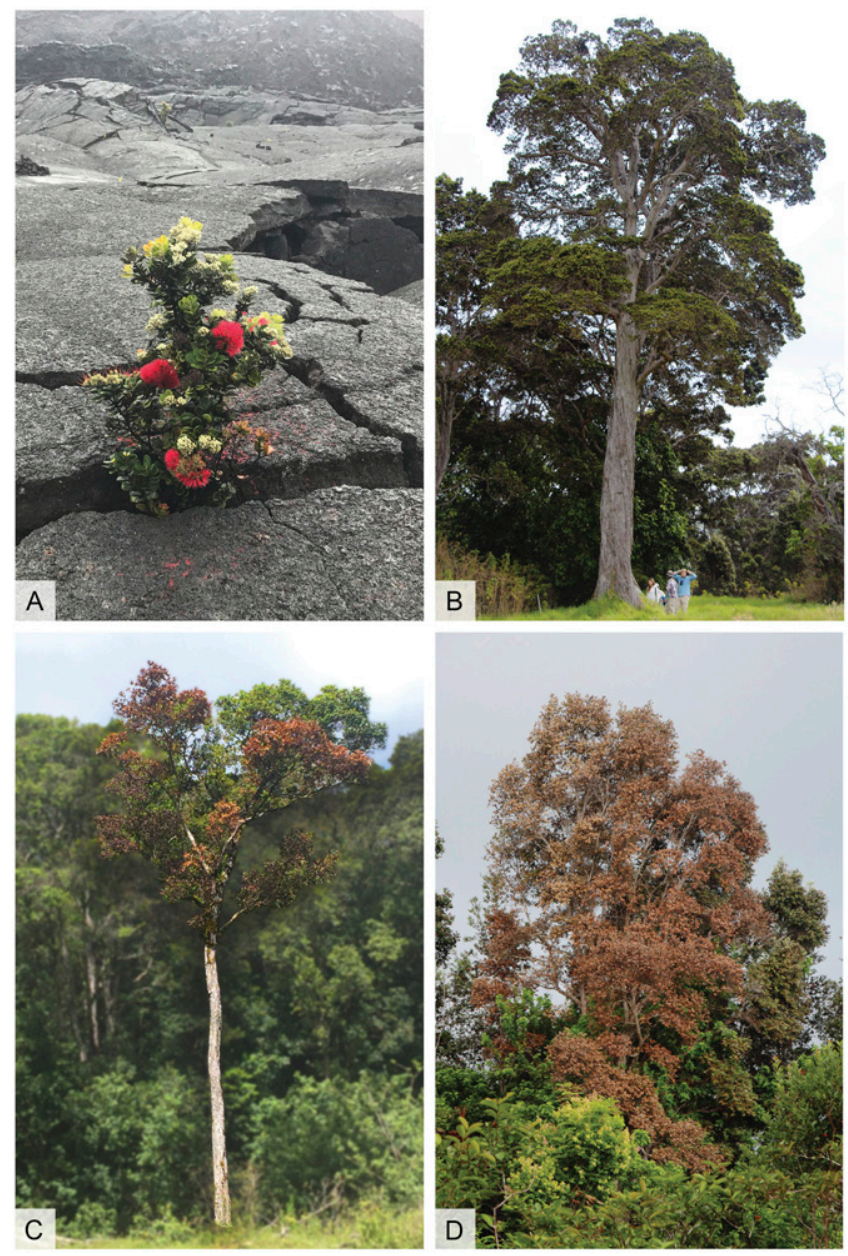

Fig. 1. 'Ōhi'a (Metrosideros polymorpha) trees and crown symptoms associated with Ceratocystis lukuohia infection. A, Healthy, flowering pioneer seedling growing from crack in lava field; $\mathbf{B}$, healthy, old-growth tree at the Hakalau Forest National Refuge, HI; C, partial and D, full crown wilt caused by C. lukuohia colonization. Photos (B, D): J. B. Friday, University of Hawai i at Mānoa. 
mock inoculated trees (PT 10 to 12) were externally asymptomatic 69 DAI (Table 1). Total length of phloem necrosis and xylem staining on wilted trees ranged from 670 to $805 \mathrm{~cm}$ (Fig. 2B). Although PT 8 had a green and asymptomatic crown, internal phloem necrosis extended $122 \mathrm{~cm}$, and xylem staining was more extensive $(390 \mathrm{~cm})$ (Fig. 2B). For C. lukuohia-inoculated trees, phloem necrosis and sapwood stain extended further above than below the inoculation sites. Control trees displayed limited phloem necrosis ( $<9 \mathrm{~cm}$ long); xylem discoloration was diffuse brown, less than $21 \mathrm{~cm}$ long, and centered on the wound site (Fig. 2B). C. lukuohia was recovered from the sapwood of carrot baits for all wood disks sampled from fungus-inoculated trees, but it was not recovered from control trees (Table 1). The maximum height for pathogen detection ranged from 240 to $690 \mathrm{~cm}$ above the inoculation site (Fig. 2B). For both pathogenicity trials, all qPCR assays confirmed $C$. lukuohia presence on representative carrot baits $(n=12)$ and in subcultures from carrot baits transferred to agar media $(n=6)$.

Colonization of artificially inoculated trees. Trees IC 1 to 6 exhibited crown wilt symptoms by 6 weeks after inoculation, regardless of inoculum type (Table 2). Each of the three trees with filter paper inoculum completely wilted by 42 DAI, compared with agarslurry inoculated trees, whose crown wilt ranged from 30 to $90 \%$ $($ mean $=53.3 \%)$. For the filter paper inoculum trees, the mean disk circumference with xylem staining ranged from 80 to $96 \%$ and mean maximum radial depth of stain was 0.46 to $1.34 \mathrm{~cm}$ into the sapwood (Table 2; Fig. 3A). The agar slurry inoculum tree with the lowest crown rating (IC 5) had a $65 \%$ mean disk circumference with staining and $0.55 \mathrm{~cm}$ mean maximum radial depth of stain (Table 2). Sapwood disks from trees IC 4 and 6 had $>98 \%$ of their mean circumference showing xylem stain and a mean maximum stain depth of $1.7 \mathrm{~cm}$.

For trees inoculated with filter paper inoculum (IC 1 to 3 ), the crowns were completely wilted (reddish-brown leaves) by 37 to 42 DAI. The main stem was forked at either $7.5 \mathrm{~m}$ or $13 \mathrm{~m}$ for two of the three trees. Continuous, dark xylem staining was observed to $\geq 93 \%$ of total tree height on either the main stem or the highest fork of each of the three trees, as well as in the second fork on two trees. Healthy phloem was seen adjacent to the highest sampled sections that had xylem staining on both the right and left forks of IC 2, but partial phloem discoloration (partly pink and partly brown) was associated with the highest sampled section on both forks of IC 1 and the main stem of IC 3 . Continuous dark staining of the xylem was observed below the inoculation points down to the cutting height $(0.2$ to $0.3 \mathrm{~m}$ above ground) of all three trees. Xylem staining also extended into an exposed stilt root of IC 1.

The agar slurry inoculated trees (IC 4 to 6 ) were single-stemmed and exhibited crown wilt symptom ratings from 30 to $90 \%$ at 42 DAI (Table 2). Continuous dark xylem staining was observed up to $11.6 \mathrm{~m}$, or $95 \%$ of total tree height, in IC 4, which had the most extensive crown wilt. In contrast, discontinuous dark staining (streaked or spotty) (Fig. 3B and C) was observed up to $8.5 \mathrm{~m}$ (64.4\% of tree height) and $13.5 \mathrm{~m}$ (93\% of tree height) in trees IC 5 and 6 , which had 30 and $40 \%$ wilted crowns, respectively (Table 2). Phloem associated with highest stem occurrence of xylem staining was generally "healthy" (pink) in IC 5, while partly pink and partly brown phloem was associated with the highest xylem staining in IC 4 and IC 6. Complete cinnamon to brown phloem necrosis was observed on lower stem sections adjacent to extensively stained xylem (Fig. 3D). Continuous dark xylem stain was observed from the inoculation points downward to the tree cutting height $(0.1$ to $0.3 \mathrm{~m})$.

For trees IC 1 to 3,18 to 29 stem disks were removed for carrotbaiting of xylem tissue, and 5 to 16 disks were used for baiting of phloem tissue (Table 3). The pathogen was recovered from 94 to $100 \%$ of the xylem samples and from 56 to $100 \%$ of the phloem samples. The maximum height of the trees from which $C$. lukuohia was isolated was the same for xylem and phloem tissues taken from two of the trees, but recovery was greater from xylem tissues than phloem for tree IC 2 (Table 3). Over $83 \%$ of the xylem sampled from 22 to 27 stained stem disks from agar slurry trees (IC 4 to 6) yielded the fungus, compared with $55 \%$ of the phloem tissues assayed from the same disks (Table 3; IC 6 depicted in Fig. 4A). The maximum height of pathogen recovery was between 11 and $13 \mathrm{~m}$ for both xylem and phloem tissue for these trees (Table 3).

Naturally infected trees. The two trees sampled in the community of Volcano, HI, had crowns that were $75 \%$ (VT1) and 25\% (VT2) wilted. Although the trees differed in outward appearance, nearly the entire length of main stem and branches of both trees had sapwood heavily stained brown to black, often with radial streaking. Mean disk circumference with sapwood stain was greater than $50 \%$, while mean maximum depth of staining was under $2.0 \mathrm{~cm}$ (Table 2). For VT1, phloem necrosis and xylem stain were visible into the small branches $(<2 \mathrm{~cm}$ diam $)$ of the upper crown to a height of $13 \mathrm{~m}$.

C. lukuohia was isolated from $94 \%$ of the stained xylem samples taken from 34 wood disks of VT1 (Table 3). The pathogen was isolated from stained xylem of six branches greater than $10 \mathrm{~m}$ above ground and from samples taken $6 \mathrm{~m}$ above ground in two other branches. Although the phloem was sparsely sampled, C. lukuohia was isolated from $60 \%$ of the assayed necrotic phloem samples from tree VT1 (Table 3). For VT2, stained xylem and necrotic phloem were observed at the top of the main stem, with discontinuous streaking in otherwise healthy xylem in small branches at over $13 \mathrm{~m}$ above ground. Of the 31 wood disks sampled from VT2, C. lukuohia was detected in $92 \%$ of the stained sapwood samples, at a maximum radial depth of $4 \mathrm{~cm}$ (Table 3). The pathogen was isolated from stained xylem and necrotic phloem from all eight main limbs of VT2, with four limbs positive at 6 to $9 \mathrm{~m}$ height and four limbs positive above $10 \mathrm{~m}$ (Fig. 4B). The pathogen was isolated from nearly all stained xylem and necrotic phloem samples taken from near the apex of the VT2 (Table 3, Fig. 4B)

Table 1. Wilting and pathogen recovery from pole-sized Metrosideros polymorpha trees after inoculation of Ceratocystis lukuohia using the agar slurry method

\begin{tabular}{|c|c|c|c|c|c|c|c|c|c|}
\hline Tree ID & $\begin{array}{c}\text { DBH } \\
(\mathrm{cm})\end{array}$ & Treatment & $\begin{array}{l}\text { Fungal } \\
\text { isolate }\end{array}$ & $\begin{array}{c}\text { Field } \\
\text { location a }\end{array}$ & $\begin{array}{c}\text { Month of } \\
\text { inoculation }\end{array}$ & $\begin{array}{l}\text { Inoculation } \\
\text { points (no.) }\end{array}$ & $\begin{array}{l}\text { Days to } \\
\text { final rating }\end{array}$ & $\begin{array}{l}\text { Wilt at final } \\
\text { rating }(\%)\end{array}$ & $\begin{array}{l}\text { Positive isolations/number } \\
\text { of discs taken at different } \\
\text { heights in the tree }\end{array}$ \\
\hline PT 1 & 11.0 & C. lukuohia & P15-02 & WFR & February & 4 & 92 & 0 & $7 / 7$ \\
\hline PT 2 & 26.5 & C. lukuohia & P15-02 & WFR & February & 8 & 92 & 0 & $3 / 3$ \\
\hline PT 3 & 13.0 & C. lukuohia & P15-02 & WFR & February & 7 & 92 & 65 & $5 / 5$ \\
\hline $\begin{array}{l}\text { PT } 4,5 \text {, } \\
\text { and } 6\end{array}$ & $18.0-26.0$ & Controls & Sterile agarb & WFR & February & 6 & 92 & 0 & $0 / 23$ \\
\hline PT 7 & 12.3 & C. lukuohia & P17-70 & KMR & August & 2 & 69 & 100 & $8 / 8$ \\
\hline PT 8 & 12.3 & C. lukuohia & P17-70 & KMR & August & 2 & 69 & 0 & $7 / 7$ \\
\hline PT 9 & 12.5 & C. lukuohia & P17-70 & KMR & August & 2 & 69 & 100 & $7 / 7$ \\
\hline $\begin{array}{l}\text { PT } 10,11, \\
\text { and } 12\end{array}$ & $11.0-11.9$ & Controls & Sterile agar ${ }^{b}$ & KMR & August & 2 & 69 & 0 & $0 / 10$ \\
\hline
\end{tabular}

\footnotetext{
${ }^{\mathrm{a}}$ WFR $=$ Waiākea Forest Reserve, KMR = Keaukaha Military Reserve.

$\mathrm{b}$ Control trees were inoculated with sterile malt yeast extract agar (MYEA) slurry.
} 


\section{Discussion}

Artificial inoculation of pole-sized $M$. polymorpha trees with $C$. lukuohia caused external wilt and internal stain symptoms typical of those described for rapid 'ōhi`a death (Barnes et al. 2018) and those observed in the naturally infected trees we evaluated. The general pattern of pathogen spread and internal symptom development based on our results is as follows. Relatively rapid longitudinal (axial) spread follows initial C. lukuohia infection as evidenced by vascular staining and isolation of the pathogen, and the pathogen moves upward much faster than downward. The upper and lower margins (or advancing front) of the longitudinal spread is characterized by discontinuous xylem staining. Necrosis of the inner phloem (mixed coral and brown colors to total necrosis) generally occurs behind the advancing front of xylem staining. In a similar fashion, lateral spread in the outer xylem lags behind the axial spread, but within several weeks to several months it can lead to staining around the circumference of the outer xylem. Inward radial spread in the xylem occurs, but penetration is generally shallow $(<2 \mathrm{~cm})$ in depth in artificially inoculated trees at 6 weeks to 3 months. The combined lateral and radial progression of staining can result in a characteristic "starburst" pattern (Supplementary Fig. S1). The fungus can survive in necrotic phloem and xylem tissues based on baiting assays.

Green (1981) and Gibbs (2001) outlined the typical progression of vascular wilt diseases in woody plants: 1) for new infections to occur, a fresh wound into or near the xylem is needed; 2) after penetration, the pathogen enters and is strictly limited to the xylem tissue, where it moves passively in the transpiration stream; and 3) upon complete colonization, the pathogen is no longer confined to xylem elements and can grow outward into the living inner bark of moribund hosts. Other general characteristics of vascular wilt diseases include crown symptoms progressing from green to brown foliage, accompanied by leaf wilt, leaf death, and defoliation, along with xylem discoloration associated with the host's resistance response. Wounds into, or near, the xylem are probably necessary for C. lukuohia infection to occur. Based on the results of our inoculation studies, the pathogen enters the xylem and rapidly moves upward and to a lesser extent downward, presumably as conidia in the flow of water during the diurnal transpiration cycle. Unlike classic vascular wilt fungi, the fungus appears to colonize living ray parenchyma and moves outward into the inner phloem of inoculated trees long before the host becomes moribund. In this respect, C. lukuohia resembles canker stain of Platanus species caused by $C$. platani and similar diseases caused by Latin American strains of Ceratocystis (Harrington 2013; Kile 1993; Tsopelas et al. 2017). However, all other characteristics we have documented lead us to classify C. lukuohia as a vascular wilt pathogen of M. polymorpha. Furthermore, we propose Ceratocystis wilt of 'ohi' a as the official name of the disease, consistent with the first report of Keith et al. (2015).

Originally, the rapid `ohi`a death pathogen was reported as $C$. fimbriata, yet further work demonstrated instead that two novel species, C. lukuohia and C. huliohia, were associated with 'ōhi' a mortality (Barnes et al. 2018; Keith et al. 2015). Seedling inoculations were inadequate to distinguish the host colonization patterns by C. lukuohia versus $C$. huliohia (Barnes et al. 2018), but inoculation of larger trees demonstrate that $C$. lukuohia causes a systemic vascular wilt that is typical of the rapid mortality and extensive sapwood staining observed in $M$. polymorpha affected by ROD in natural landscapes. Thus, Ceratocystis wilt of 'ōi`a represents the disease caused by C. lukuohia, and Ceratocystis wilt falls under the more broadly recognized condition of ROD. Parallel field experiments were conducted with $C$. huliohia on similar-sized, forest M. polymorpha. Results will be published separately, but preliminary findings indicate $C$. huliohia is not a systemic wilt pathogen (J. Juzwik, unpublished data).

At the time of harvest, tangential colonization around the circumference of the outer sapwood was nearly complete in our inoculated trees but was less so in the naturally infected trees (Supplementary Fig. S2). This may be an artifact of the inoculation procedure, in which trees received a high dosage of inoculum into two (or more) wounds on opposite sides of the stem. In laurel wilt and oak wilt, caused by Raffaelea lauricola T.C. Harr., Fraedrich \& Aghayeva and Bretziella fagacearum (Bretz) Z.W.deBeer, Marinc., T.A. Duong \& M.J. Wingf., respectively, a complete ring of brownblack discoloration that encircles the outer sapwood is seen only in the most recent annual rings, with little or no radial streaking along the ray parenchyma (Bretz 1953; Hughes et al. 2015). The internal vascular discoloration caused by $C$. lukuohia resembles that of $C$. fimbriata and C. platani in earlier stages of colonization, where distinct and separate longitudinal streaks are visible in the outer sapwood, along with radial streaking in cross-sections (Harrington 2013; Tsopelas et al. 2017). In heavily colonized or recently killed

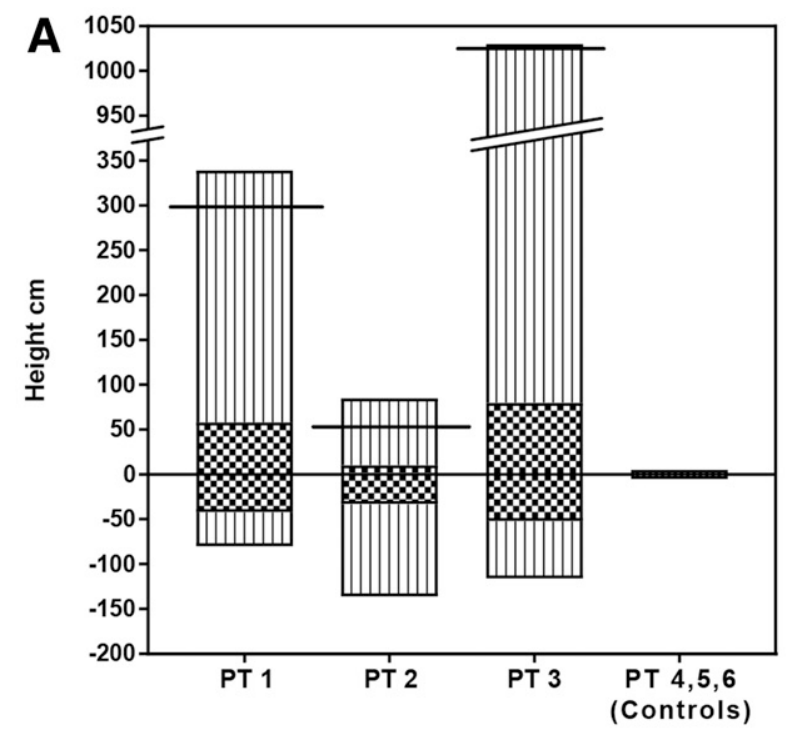

Tree

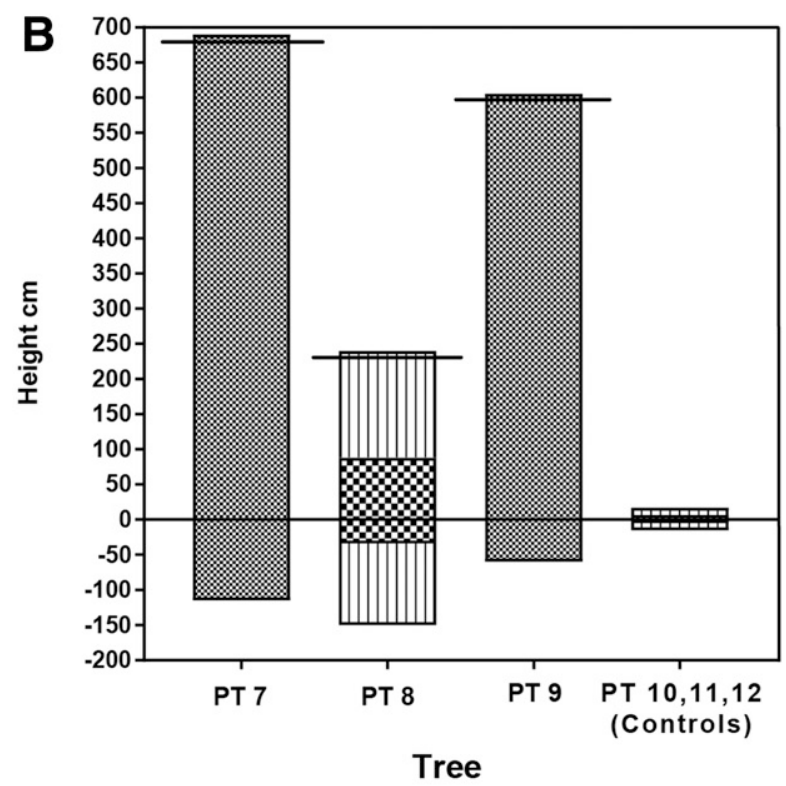

Equal colonization of
xylem and phloem

Fig. 2. Extent of internal staining and Ceratocystis lukuohia colonization in the main stem of artificially inoculated 'ōhi'a trees in field pathogenicity trials. Bars denote extent of internal xylem staining and phloem necrosis. The inoculation point is indicated at height " 0 " and horizontal solid black lines indicate maximum longitudinal extent of pathogen recovery in sapwood. A, Feb. to May 2017 trial; B, late Aug. to early Nov. 2017 trial. Data from three control trees are shown as mean of three replicates. 
'ōhi a trees, C. lukuohia staining continues to intensify and penetrate radially and tangentially, eventually resulting in a wide band of stained sapwood across the entire cross-section.

In general, $C$. lukuohia penetrated deeper radially in the sapwood of naturally infected versus artificially inoculated trees. For the two naturally infected and symptomatic trees, C. lukuohia was isolated from stained xylem at a depth of 2 and $4 \mathrm{~cm}$. Based on observations in dozens of dissected `ohi 'a trees killed by C. lukuohia, it appears that the fungus continues to penetrate radially toward the center of the tree after death, even into the red pathological heartwood tissues. Such sapwood colonization after death would be advantageous for the fungus as aleurioconidia in such tissue can serve as windborne inoculum if liberated as sawdust or ambrosia beetle frass (Harrington 2013; Roy et al. 2019).

C. lukuohia is an aggressive vascular pathogen that spreads throughout host trees, causing rapid wilt and mortality. Artificial inoculations resulted in whole-tree mortality and isolation of the pathogen at a height of over 10 meters above the inoculation points in under 100 days. Based on observed staining and results of carrot-baiting assays, the pathogen could move up from the inoculation point more than $10 \mathrm{~cm}$ per day, much faster than linear growth in a Petri dish on malt agar media. This pattern of movement is typical among vascular wilts where the spores of the pathogen are passively moved upward within the sap stream during transpiration (Gibbs 2001; Green 1981). With laurel wilt, Mayfield et al. (2008) were able to induce disease symptoms with
R. lauricola in field-inoculated Persea borbonia trees within 3.5 months using a single inoculation point, and in susceptible red oaks (Quercus section Lobatae) infected with oak wilt, symptoms can develop within weeks of infection (Juzwik et al. 2011). Like our results, Henry and Riker (1947) isolated the oak wilt pathogen (B. fagacearum) from the apex of most limbs of a stem-inoculated Quercus velutina soon after observable symptoms. These results indicated that extensive xylem spread of pathogen propagules can occur prior to the development of wilt. In artificially inoculated $M$. polymorpha, the pathogen also moved downward in the sapwood to a limited extent, perhaps in the sap stream during the nocturnal portion of diurnal sap flow, when the xylem tension relaxes. Similar to other vascular wilt pathogens, it is likely that C. lukuohia triggers the formation of tyloses, gums, and polysaccharides in vessel elements, which can result in occlusion and reduction of water conductance (Inch and Ploetz 2012; Inch et al. 2012; Ouellette 1962; Pomerleau 1970).

Within this study, both forms of inoculum used (filter paper and agar slurry) were able to induce disease in M. polymorpha. In the June inoculation trials, filter paper inoculum resulted in a higher percentage of crown wilt than the agar slurry, although the agar slurry inoculum had more fungal mass. Both inoculum types resulted in a similar amount of stained disc circumference, and radial staining penetrated slightly deeper with the agar slurry inoculum. Agar slurry inoculations for pathogenicity (February) and colonization studies (June and August) were conducted when monthly average

Table 2. Tree characteristics, crown wilt information, and internal symptom development for six trees artificially inoculated with Ceratocystis lukuohia and two naturally infected Metrosideros polymorpha trees ${ }^{\mathrm{a}}$

\begin{tabular}{|c|c|c|c|c|c|c|c|c|c|}
\hline \multirow{2}{*}{\multicolumn{4}{|c|}{ Tree characteristics }} & \multicolumn{2}{|c|}{ Crown wilt } & \multicolumn{2}{|c|}{ Sample distribution } & \multicolumn{2}{|c|}{ Vascular stain characteristics } \\
\hline & & & & \multirow{2}{*}{$\begin{array}{l}\text { Days to } \\
\text { final } \\
\text { rating }\end{array}$} & \multirow{2}{*}{$\begin{array}{c}\text { Wilt at } \\
\text { felling } \\
(\%)\end{array}$} & \multirow{2}{*}{$\begin{array}{c}\text { Main or forked } \\
\text { stem ht. sampled } \\
\text { (m) }\end{array}$} & \multirow{2}{*}{$\begin{array}{l}\text { Main or forked } \\
\text { stem disks } \\
\text { taken (no.) }\end{array}$} & \multirow{2}{*}{$\begin{array}{c}\text { Mean disk } \\
\text { circumference with } \\
\text { stain }(\% \pm \mathrm{SE})\end{array}$} & \multirow{2}{*}{$\begin{array}{l}\text { Mean disk max. } \\
\text { depth of stain } \\
(\mathrm{cm} \pm \mathrm{SE})\end{array}$} \\
\hline ID & $\begin{array}{l}\text { Ht. } \\
\text { (m) }\end{array}$ & $\begin{array}{c}\mathrm{DBH} \\
(\mathrm{cm})\end{array}$ & $\begin{array}{c}\text { Inoculum } \\
\text { type }^{b}\end{array}$ & & & & & & \\
\hline IC 1 & 13.9 & 15 & FP & 37 & 100 & 0.4 to 3.1 & 7 & $95.0 \pm 3.3$ & $1.34 \pm 0.10$ \\
\hline IC 2 & 16.7 & 16.3 & FP & 42 & 100 & 1.1 to 5.6 & 10 & $95.5 \pm 1.0$ & $0.85 \pm 0.05$ \\
\hline IC 3 & 10.1 & 12.5 & FP & 42 & 100 & 0.2 to 1.0 & 4 & $79.7 \pm 6.8$ & $0.46 \pm 0.07$ \\
\hline IC 4 & 12.1 & 12.7 & AS & 42 & 90 & 0.4 to 2.8 & 7 & $99.3 \pm 0.1$ & $1.66 \pm 0.08$ \\
\hline IC 5 & 13.2 & 14 & AS & 42 & 30 & 0.3 to 5.3 & 12 & $65.2 \pm 5.9$ & $0.55 \pm 0.05$ \\
\hline IC 6 & 15.1 & 14.5 & AS & 42 & 40 & 0.2 to 3.8 & 9 & $98.1 \pm 1.4$ & $1.68 \pm 0.07$ \\
\hline VT 1 & 15 & 25.8 & Nat & $\mathrm{n} / \mathrm{a}$ & 75 & 0.2 to 9.8 & 16 & $63.5 \pm 5.4$ & $1.80 \pm 0.12$ \\
\hline VT 2 & 13.7 & 23.6 & Nat & $\mathrm{n} / \mathrm{a}$ & 25 & 0.2 to 9.4 & 11 & $71.0 \pm 3.9$ & $1.47 \pm 0.12$ \\
\hline
\end{tabular}

a Trees were inoculated in June and felled in late July 2017. Naturally infected trees were felled early August 2017.

b Ceratocystis lukuohia inoculum type. FP = filter paper inoculum, AS = agar slurry inoculum, Nat = natural infection.

c Wood discs $(8.0 \mathrm{~cm}$ thick) removed from main stem or stem fork at 50 to $70 \mathrm{~cm}$ intervals between sampled endpoints.
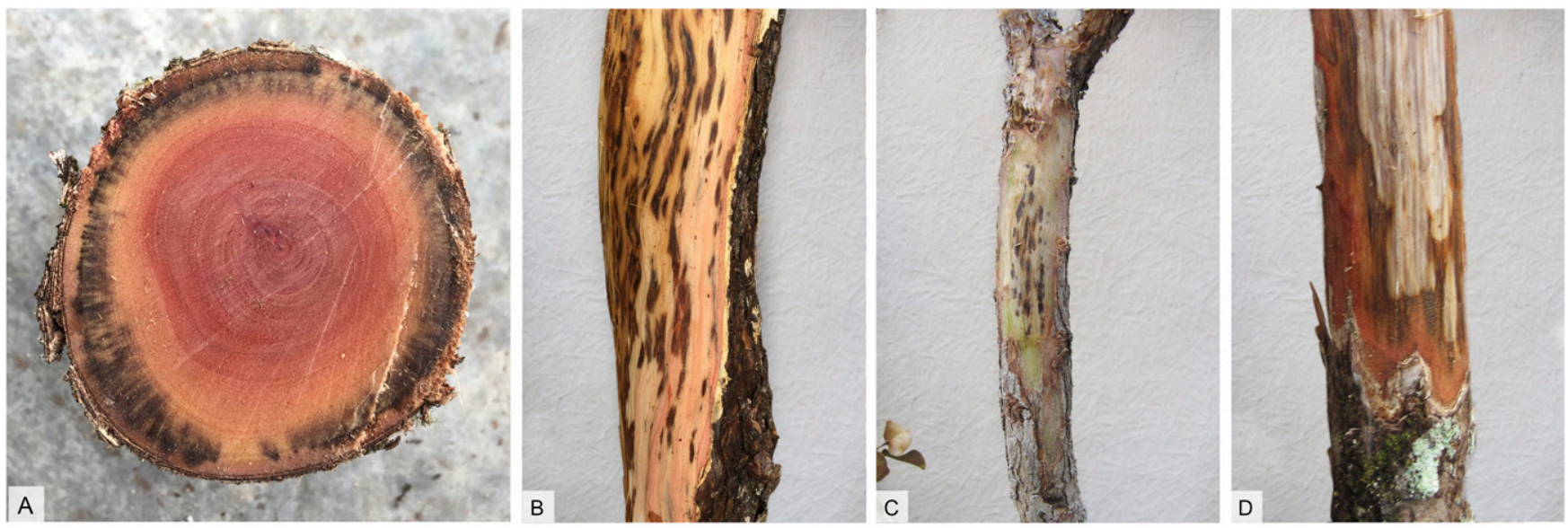

Fig. 3. Internal symptom development in Metrosideros polymorpha inoculated with Ceratocystis lukuohia. A, transverse section of cut log depicting the radial sapwood staining pattern. B and C, discontinuous brownish-black staining in sapwood under bark of main stem and in a small branch, respectively. D, cinnamon to brown phloem necrosis and internal sapwood staining in a partially de-barked stem. 
temperature highs ranged from $\sim 26$ to $29^{\circ} \mathrm{C}$, and disease severity increased with rising temperatures, suggesting seasonality may affect severity. However, other factors (fungal isolate, host genotype, etc.) may also contribute to variability in disease progression. For canker stain of plane trees (caused by $C$. platani), inoculations in spring and summer resulted in more rapid disease progression than in late autumn (Pilotti et al. 2016; Tsopelas et al. 2017). American elm and red oaks are most susceptible to Dutch elm disease (caused by Ophiostoma ulmi and $O$. novo-ulmi Brasier) and oak wilt, respectively, in spring and early summer, when large springwood vessels are produced (Juzwik et al. 2011; MacDonald and Hindal 1981).
M. polymorpha growing in Hawaii does not produce traditional growth rings of summer and springwood vessels; however, vessels are generally larger in the outer sapwood than those closer to the center of the stem (Fisher et al. 2007). The larger vessels in the outer sapwood, where wounding is more likely to occur, may contribute to the susceptibility of $M$. polymorpha, because wider and longer vessels are correlated with more susceptible phenotypes in elm species (Elgersma 1970; Solla and Gil 2002). Fisher et al. (2007) found that higher elevation $M$. polymorpha populations have narrower vessels when compared with lower elevation populations. Further research is needed to assess if, and to what extent, the roles of seasonality,

Table 3. Detection of Ceratocystis lukuohia by carrot-baiting of symptomatic sapwood or phloem tissue from stem disk samples taken from six artificially inoculated and two naturally infected Metrosideros polymorpha trees ${ }^{\mathrm{a}}$

\begin{tabular}{|c|c|c|c|c|c|c|c|c|}
\hline \multirow[b]{2}{*}{ Tree ID $^{\mathbf{b}}$} & \multirow[b]{2}{*}{$\begin{array}{c}\text { Main or forked stem } \\
\text { sample heights } \\
\text { (range in m) }\end{array}$} & \multirow[b]{2}{*}{$\begin{array}{l}\text { Wood disks } \\
\text { taken }\left(\text { no.) }^{c}\right.\end{array}$} & \multicolumn{3}{|c|}{ Sapwood } & \multicolumn{3}{|c|}{ Phloem } \\
\hline & & & $\begin{array}{l}\text { Samples } \\
\text { assayed } \\
(\text { no. })^{\mathbf{d}}\end{array}$ & $\begin{array}{c}\text { Fungus- } \\
\text { positive } \\
\text { samples (no.) }\end{array}$ & $\begin{array}{l}\text { Max. stem height } \\
\text { of positive } \\
\text { samples (m) }\end{array}$ & $\begin{array}{l}\text { Samples } \\
\text { assayed } \\
\text { (no.) }\end{array}$ & $\begin{array}{c}\text { Fungus- } \\
\text { positive } \\
\text { samples (no.) }\end{array}$ & $\begin{array}{c}\text { Max. stem height } \\
\text { of positive } \\
\text { samples (m) }\end{array}$ \\
\hline IC 1 & $0.4-13.2$ & 26 & 28 & 28 & 13.2 & 5 & 5 & 13.2 \\
\hline IC 2 & $1.1-15.4$ & 29 & 35 & 33 & 15.4 & 16 & 9 & 12.7 \\
\hline IC 3 & $1.3-9.6$ & 18 & 18 & 18 & 9.2 & 5 & 5 & 9.2 \\
\hline IC 4 & $0.4-11.5$ & 22 & 25 & 23 & 11.5 & 5 & 3 & 11.5 \\
\hline IC 5 & $0.3-12.1$ & 23 & 30 & 25 & 11.4 & 11 & 6 & 11.4 \\
\hline IC 6 & $0.2-14.2$ & 27 & 32 & 28 & 13.5 & 12 & 9 & 13.5 \\
\hline VT 1 & $0.2-13.1$ & 34 & 49 & 46 & 13.1 & 5 & 3 & 9.8 \\
\hline VT 2 & $0.2-13.3$ & 31 & 49 & 45 & 13.3 & 15 & 14 & 13.3 \\
\hline
\end{tabular}

a Trees were inoculated in June and felled in late July 2017. Naturally infected trees were felled early August 2017.

b IC 1 through IC 3 = artificially inoculated using filter paper inoculum; IC 4 through IC $6=$ artificially inoculated using agar slurry inoculum; VT 1 and VT 2 were naturally infected trees.

${ }^{c}$ Wood discs $(8.0 \mathrm{~cm}$ thick) removed from main stem or stem fork at 50 to $70 \mathrm{~cm}$ intervals between sampled endpoints.

${ }^{\mathrm{d}}$ Some wood discs were radially subsampled at intervals of $1 \mathrm{~cm}$ depth.

e Positive = Perithecia of $C$. lukuohia detected on carrot baits or, occasionally, mycelium on colonized baits identified using qPCR method of Heller and Keith (2018)

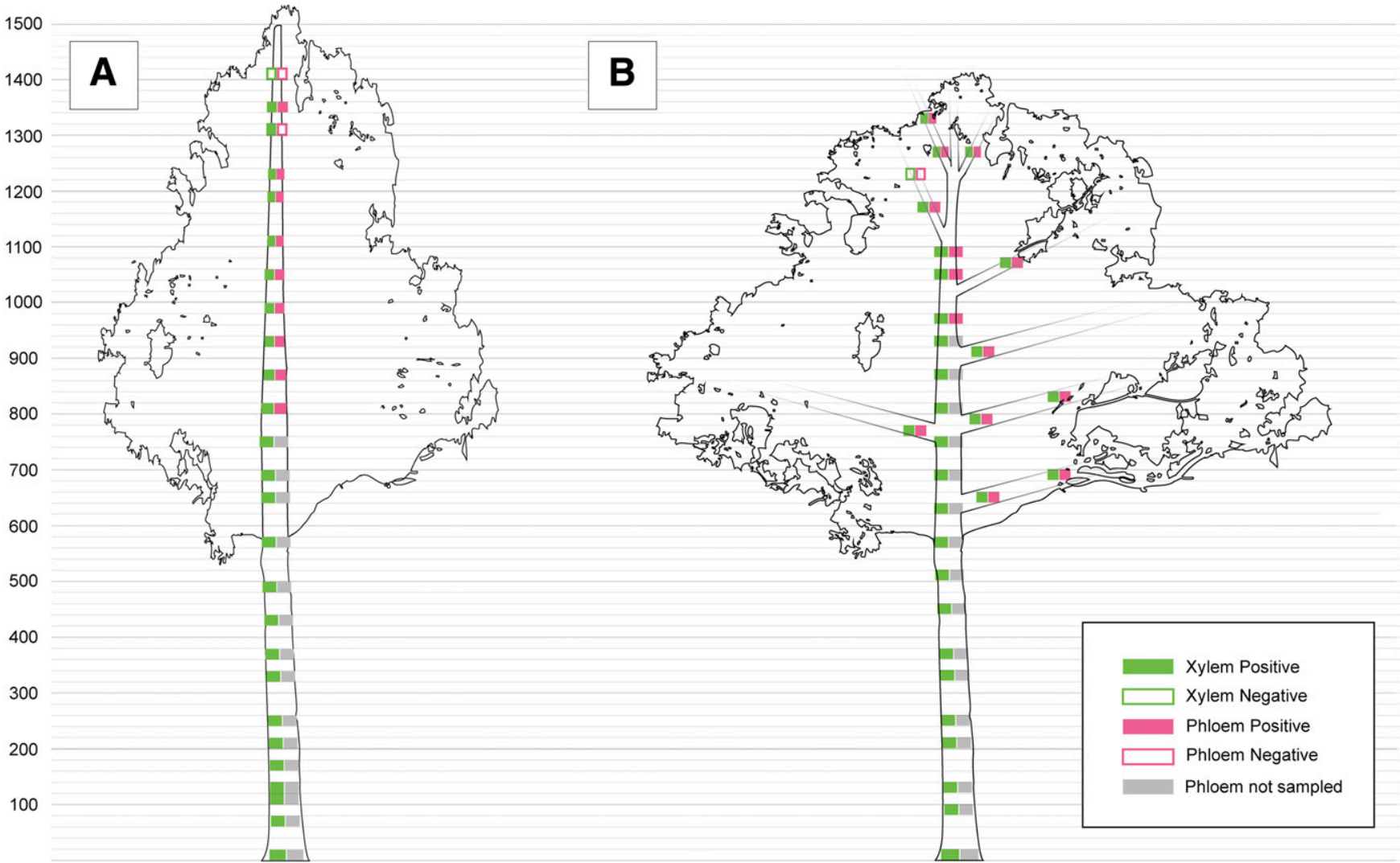

Fig. 4. Sample locations for viable Ceratocystis lukuohia in an A, artificially inoculated (IC6) and B, naturally infected (VT2) Metrosideros polymorpha trees. The pathogen was detected using a carrot baiting assay. Tree IC6 was inoculated mid-June and felled late July 2017. Tree VT2 was felled in early August 2017. 
elevation, and xylem anatomy play in `ōi`a susceptibility and Ceratocystis wilt.

The epidemiology of Ceratocystis wilt of 'ōhi`a is currently under investigation. Like other vascular wilts and Ceratocystis-caused diseases, exposed xylem wounds are likely necessary for pathogen ingress and colonization (Harrington 2013). Bark wounding and stripping by feral ungulates (sheep, goats, cattle, pigs) and branch breakage by strong winds may provide suitable infection courts for the pathogen. Insects may disperse conidia or ascospores to wounds, or wounds may be infected by contaminated tools or machinery. However, contaminated ambrosia beetle frass or sawdust are typically important sources of airborne or waterborne inoculum for Ceratocystis spp. in the Latin American Clade, such as C. lukuohia (Barnes et al. 2018; Harrington 2013; Souza et al. 2013). Exotic ambrosia beetles in the genus Xyleborus are commonly found infesting dead `ōhi a trees at lower elevation sites. Roy et al. (2019) found a high percentage $(62 \%)$ of ambrosia beetle galleries in trees killed by ROD released frass that contained $C$. lukuohia DNA, and the fungus was isolated from $17 \%$ of the frass samples. The potential of ambrosia beetles to act as direct vectors is under investigation. Unlike Dutch elm disease, oak wilt, and canker stain of plane tree (Harrington 2013; Juzwik et al. 2011), there is lack of evidence of root-grafting between $M$. polymorpha, and expanding centers of mortality associated with root graft transmission have not been evident in `ōhi a forests.

'Ōhi a, Hawai i's most prominent native tree, is ecologically, economically, and culturally important. Collectively, 'ōhi'a dominated forests support a variety of native plant and animal species and provide critical habitat for rare native birds and insects. On Hawai i Island, Fortini et al. (2019) found 38 threatened and endangered plant species in 13 endemic genera whose geographical distributions overlap that modeled for C. lukuohia, and the ranges of six of those species overlap the pathogen by more than $95 \%$. This suggests serious potential downstream effects on other species in `ōi a forests. In addition, these forests overwhelmingly constitute the upper watersheds that provide Hawai' i's citizens with clean drinking and agricultural water. Native forests on Hawai i Island are experiencing an ecological crisis of widespread mortality referred to as ROD. We have shown that `ōi`a is highly susceptible to Ceratocystis wilt caused by C. lukuohia, which is believed responsible for the epidemic levels of mortality first noted a decade ago. The disease caused by Ceratocystis huliohia, the second ROD pathogen, appears to be less important and is distinct in its pattern of host colonization (Barnes et al. 2018), and this is being further investigated. Further research is being conducted to determine the host range of $C$. lukuohia, and its potential effects on agricultural crops in Hawai'i. Research by a consortium of collaborators on disease management strategies is ongoing to protect this vital Hawaiian keystone species. Other Pacific regions and areas with native Metrosideros species, including New Caledonia, Tahiti, and New Zealand, should be aware of this pathogen and potential effects on their forests. Since there is currently no cure for Ceratocystis wilt of 'ōhi'a, enhanced biosecurity with measures for prevention and early detection are critical.

\section{Acknowledgments}

We appreciate the administrative assistance of Craig Blaisdell of the Keaukaha Military Reservation and Steve Bergfeld and Robert Hauff of the Hawai i Division of Forestry and Wildlife for providing access to study sites. We thank Chris Graper (Hawai'i Division of Forestry), Lionel Sugiyama, Eva Brill, and Blaine Luiz (USDA-ARS) for laboratory and field assistance and Kelsey Hughes provided figure design, and the helpful discussions with J. B. Friday (University of Hawai i at Mānoa) are appreciated. We thank R. A. Blanchette and J. B. Friday for their helpful comments and suggestions on the pre-submission version of the manuscript.

\section{Literature Cited}

Asner, G. P., Martin, R. E., Keith, L. M., Heller, W. P., Hughes, M. A., Vaughn, N. R., Hughes, R. F., and Balzotti, C. 2018. A spectral mapping signature for the rapid ohia death (ROD) pathogen in Hawaiian forests. Remote Sens. 10:404

Barnes, I., Fourie, A., Wingfield, M. J., Harrington, T. C., McNew, D. L., Sugiyama, L. S., Luiz, B. C., Heller, W. P., and Keith, L. M. 2018. New Ceratocystis species associated with rapid death of Metrosideros polymorpha in Hawai i. Persoonia 40:154-181.
Bretz, T. W. 1953. Oak wilt, a new threat. Pages 851-855 in: Yearbook of Agriculture. U.S. Government Printing Office, Washington, DC.

Brill, E., Hughes, M. A., Heller, W., and Keith, L. M. 2019. First report of Ceratocystis lukuohia on Metrosideros polymorpha on the island of Kaua'i, Hawai'i. Plant Dis. 103:2961.

Dawson, J. W., and Stemmerman, R. L. 1990. Metrosideros (Gaud.). Pages 964-970 in: Manual of flowering plants of Hawai'i. W. L. Wagner, D. R. Herbst, and S. H. Summer, eds. University of Hawai i Press, Honolulu, Hawai i.

Dennison, D. 2019. 07/31/19 - Rapid 'ōi'a death now detected on four islands. Hawaii Department of Land and Natural Resources. https://dlnr.hawaii.gov/ blog/2019/07/31/nr19-141/.

Elgersma, D. M. 1970. Length and diameter of xylem vessels as factors in resistance of elms to Ceratocystis ulmi. Neth. J. Pl. Path. 76:179-182.

Fisher, J. B., Goldstein, G., Jones, T. J., and Cordell, S. 2007. Wood vessel diameter is related to elevation and genotype in the Hawaiian tree Metrosideros polymorpha (Myrtaceae). Am. J. Bot. 94:709-715.

Fortini, L. B., Kaiser, L. R., Keith, L. M., Price, J., Hughes, R. F., Jacobi, J. D., and Friday, J. B. 2019. The evolving threat of Rapid 'Ōhi'a Death (ROD) to Hawai'i's native ecosystems and rare plant species. For. Ecol. Manage. 448:376-385.

Gibbs, J. N. 2001. Vascular wilt diseases of trees- An Anglo-American perspective. Pages 15-29 in: Shade tree wilt diseases. C. L. Ash, ed. The American Phytopathological Society, St. Paul, MN.

Green, R. J., Jr. 1981. An overview. Pages 1-24 in: Fungal Wilt Diseases of Plants. M. E. Mace, A. A. Bell, and C. H. Beckman, eds. Academic Press, Inc., New York.

Harrington, T. C. 2013. Ceratocystis diseases. Pages 230-255 in: Infectious forest diseases. P. Gonthier and G. Nicolotti, eds. CAB International, Wallingford, UK.

Heller, W. P., Hughes, M. A., Luiz, B. C., Brill, E., Friday, J. B., Williams, A. M., and Keith, L. M. 2019. First report of Ceratocystis huliohia causing mortality of Metrosideros polymorpha trees on the Island of Kaua'i, Hawai' $i$ USA.For. Pathol. 49:e12546.

Heller, W. P., and Keith, L. M. 2018. Real-time PCR assays to detect and distinguish the Rapid 'Ōhi'a Death pathogens Ceratocystis lukuohia and C. huliohia. Phytopathology 108:1395-1401.

Henry, B. W., and Riker, A. J. 1947. Wound infection of oak trees with Chalara quercina and its distribution within the host. Phytopathology 37:735-743.

Hodges, C. S., Adee, K. T., Stein, J. D., Wood, H. B., and Doty, R. D. 1986 Decline of ohia (Metrosideros polymorpha) in Hawaii: a review. USDA Forest Serv. Gen. Tech. PSW-86. Pacific Southwest Forest and Range Exp. Stn, Berkeley, CA.

Hughes, M. A., Smith, J. A., Ploetz, R. C., Kendra, P. E., Mayfield, A. E., III Hanula, J. L., Hulcr, J., Stelinski, L. L., Cameron, S., Riggins, J. J., Carrillo, D., Rabaglia, R., Eickwort, J., and Pernas, T. 2015. Recovery plan for laurel wilt on redbay and other forest species caused by Raffaelea lauricola and disseminated by Xyleborus glabratus. Plant Health Prog. 16:173-210.

Inch, S. A., and Ploetz, R. C. 2012. Impact of laurel wilt, caused by Raffaelea lauricola, on xylem function in avocado, Persea americana. For. Path. 42:239-245.

Inch, S. A., Ploetz, R. C., Held, B., and Blanchette, R. 2012. Histological and anatomical responses in avocado, Persea americana, induced by the vascular wilt pathogen, Raffaelea lauricola. Botany 90:627-635.

Juzwik, J., Appel, D. N., MacDonald, W. L., and Burks, S. 2011. Challenges and successes in managing oak wilt in the United States. Plant Dis. 95:888-900.

Keith, L. M., Hughes, R. F., Sugiyama, L. S., Heller, W. P., Bushe, B. C., and Friday, J. B. 2015. First report of Ceratocystis wilt on 'ōhi'a (Metrosideros polymorpha). Plant Dis. 99:1276.

Kile, G. A. 1993. Plant diseases caused by species of Ceratocystis sensu stricto and Chalara. Pages 173-183 in: Ceratocystis and Ophiostoma: Taxonomy, Ecology, and Pathogenicity. M. J. Wingfield, K. A. Seifert, and J. F. Webber, ed. The American Phytopathological Society, St. Paul, MN.

Li, Q., Harrington, T. C., McNew, D., and Li, J. 2017. Ceratocystis uchidae, a new species on Araceae in Hawaii and Fiji. Mycoscience 58:398-412.

MacDonald, W. L., and Hindal, D. F. 1981. Life cycle and epidemiology of Ceratocystis. Pages 113-144 in: Fungal Wilt Diseases of Plants. M. E. Mace, A. A. Bell, and C. H. Beckman, eds. Academic Press, Inc., New York, NY.

Mayfield, A. E., III, Barnard, E. L., Smith, J. A., Bernick, S. C., Eickwort, J. M. and Dreaden, T. J. 2008. Effect of propiconazole on laurel wilt disease development in redbay trees and on the pathogen in vitro. Arboric. Urban For. 34:317-324

Moller, W. J., and DeVay, J. E. 1968. Carrot as a species-selective isolation medium for Ceratocystis fimbriata. Phytopathology 58:123-126.

Mortenson, L. A., Hughes, R. F., Friday, J. B., Keith, L. M., Barbosa, J. M., Friday, N. J., Liu, Z., and Sowards, T. G. 2016. Assessing spatial distribution, stand impacts and rate of Ceratocystis fimbriata induced 'ōhi'a (Metrosideros polymorpha) mortality in a tropical wet forest, Hawai'i Island, USA. For. Ecol. Manage. 377:83-92.

Mueller-Dombois, D. 1985. 'Ōhi'a dieback in Hawaii: 1984 synthesis and evaluation. Pac. Sci. 39:150-170.

Mueller-Dombois, D., Jacobi, J. D., Boehmer, H. J., and Price, J. P. 2013. `Ōhi`a Lehua Rainforest: Born Among Hawaiian Volcanoes, Evolved in Isolation: The Story of a Dynamic Ecosystem with Relevance to Forests Worldwide. Friends of the Joseph Rock Herbarium, Honolulu, HI. 
Ouellette, G. B. 1962. Studies on the infection process of Ceratocystis ulmi (Buism.) C. Moreau in American elm trees. Can. J. Bot. 40:1567-1575.

Petteys, E. Q. P., Burgan, R. E., and Nelson, R. E. 1975. Ohia forest decline: its spread and severity in Hawaii. USDA Forest Serv. Res. Paper PSW-105. Pacific Southwest Forest and Range Exp. Stn, Berkeley, CA.

Pilotti, M., Di Lernia, G., Modesti, V., Lumia, V., Brunetti, A. 2016. Outcome of Ceratocystis platani inoculations in Platanus $\times$ acerifolia in relation to season and inoculum dose. iForest Biogeosci. For. 9:608-617.

Pomerleau, R. 1970. Pathological anatomy of the Dutch elm disease. Distribution and development of Ceratocystis ulmi in elm tissues. Can. J. Bot. 48:2043-2057.

Roy, K., Ewing, C. P., Hughes, M. A., Keith, L., and Bennett, G. M. 2019. Presence and viability of Ceratocystis lukuohia in ambrosia beetle frass from Rapid 'Ōhi'a Death-affected Metrosideros polymorpha trees on Hawai'i Island.For. Pathol. 49:e12476.
Solla, A., and Gil, L. 2002. Xylem vessel diameter as a factor in resistance of Ulmus minor to Ophiostoma novo-ulmi.For. Pathol. 32:123-134.

Souza, A. G. C., Maffia, L. A., Murta, H. M., Alves, Y. H., Pereira, R. M., and Picano, M. C. 2013. First report on the association between Ceratocystis fimbriata, an agent of mango wilt, Xyleborus affinis, and the sawdust produced during beetle colonization in Brazil. Plant Dis. 97:1116.

Thorpe, D. J., Harrington, T. C., and Uchida, J. Y. 2005. Pathogenicity, internal transcribed spacer-rDNA variation, and human dispersal of Ceratocystis fimbriata on the family Araceae. Phytopathology 95:316-323.

Tsopelas, P., Santini, A., Wingfield, M. J., and de Beer, Z. W. 2017. Canker stain: a lethal disease destroying iconic plane trees. Plant Dis. 101:645-658.

Vaughn, N. R., Asner, G. P., Brodick, P. G., Martin, R. E., Heckler, J. W., Knapp, D. E., and Hughes, R. F. 2018. An approach for high-resolution mapping of Hawaiian forest mortality using laser-guided imaging spectroscopy. Remote Sens. 10:502. 